a year, is far more than proportionate to the general increase of population, and is not sufficiently accounted for by the fact that more people are now declared mad than used to be so formerly. Dr. Maudsley proceeds, in pages (200-258) marked by cautious statement and the stamp of a wide experience, to trace the causes of this increase to the varied excitements of English life. We should like to see the whole of the chapter "On the Causes of Insanity" reprinted by itself in a cheap form for wider circulation.-The Saturday Review, May 25th.

\title{
Was Luther Mad?
}

Ix the recent trial, in which the validity of the will of Mrs.jThwaites was disputed, because of the extreme religious delusions which she was proved to have had for many years, Mr. Serjeant Ballantine elicited from Dr. Williams

- Religious Hallucinations.-Whatever be the issue of the singular will case which has been occupying the attention of the Court of Probate for so many days, it may possibly contribute some little towards the settlement of the unsatisfactory state of English law as to the condition of mind which constitutes what is termed " testamentary incapacity." The arguments against the validity of Mrs. Thwaites's will raise, in fact, one of the most difficult psychological and social problems that can be imagined. Did the religious hallucinations under which she laboured con. stitute real legal insanity? And if she was really insane, is there any truth in the theory of one of the doctors who were examined, who held that a person may be mad on religious subjects, and yet perfectly sane upon all others? There is also a still further question involved. Onght all insanity, as such, necessarily to incapacitate a person from disposing of his property by will? And then there is the practical question, what constitutes a religious hallucination so entirely a delusion that it may be held to be the product of a disordered mind, and yet at the same time be compatible with practical sanity on all secular matters? Or, to state the difficulty from another point of view, is it possible to be mad on religious topics without suffering from disease of the brain, either organic or functional? To answer these questions, even in the most hesitating way, would be, of course, impossible in the space of a paragraph. But it may be useful to suggest one or two of the difficulties which surround the subject, from whichever point of it is approached. Insanity, says modern pathology, is a disease of the brain ; but in many cases how do we know that the brain really is diseased, except from the occurrence of certain mental phenomena, which may, after all, be the result of mere defective processess of reasoning, having no connection whatever with physical disease? In such cases we are driven to argue in a circle. Such and such a man is not responsible for his actions, and is incapable of making a legal will, because his brain is disordered. But how do we know his brain is disordered? Because his acts are inconsistent with the laws of reasoning. But is everybody who cannot reason to be held legally insane? No; only when the brain is diseased. But how do wo know this in the one case before us? and so on, round and round without end. The truth is that, especially in religious subjects, we have often no recognised tests as to what constitutes insanity. For instance, supposing that a will was found to contain a clause for providing a proper personal reception in the way of house, attendants, and ceremonial for the Founder of Christianity on his appearing in London on such and such a date, would any jury hesitate to hold this provision a conclusive proof of the testator's madness ? Yet how would this provision differ from the practice of the Irvingite body, who at one time made preparations in their churches for the possible appearance of Jesus Christ among them? They may do it still, for all we know. They certainly practised the "speaking in unknown tongues," under the belief of being personal instruments of the Holy Ghost, until very recently.-Pall Mall Gazette. 
of Bethlem Hospital, in cross-examination, a confession of opinion that Luther was mad, or, at any rate, not altogether sane. Dr. Wood is stated in the newspaper reports to have given similar evidence. Whatever we may think of their opinion, we must admire the rare candour of these physicians ; for the admission was anything but calculated to serve the cause in the defence of which they were called.

But was Luther mad? The spiritual temptations which he underwent he described as buffetings of Satan; with these he was frequently tormented; he called them conflicts between him and Satan. 'The terrors he experienced he called the devil's traps, from which he earnestly prayed God to deliver him. If this were madness, then every preacher who describes the evil impulses of the heart as the instigations of Satan is surely mad himself, and teaches mad. ness to his hearers; and that, too, without the excuse which Luther had in the iguorance and superstitious credulity of the times in which be lived. The manner in which tuther himself speaks of his temptations is interesting, for it resembles the way in which he speaks of insanity. "I think," he says, "that all fools, and such as bave not the use of reason, are vexed or led aside by Satan ; not that they are therefore condemned, but because Satan doth diversely tempt men, some grievously, some easily; some a longer, some a shorter time. And whereas physicians attribute much to natural means sometimes, this cometh to pass because they know not how great the power and the strength of the devils are." This, though it lack form a little, according to modern scientic ideas of insanity, is "not like madness."

But let us go on to hear how he speaks of his conversations with the devil, whose persecutions cost him many a bitter night-multus noctes mihi satis amarulentas et acerbas reddere ille novit. "The devil," he says, "knows how to invent, and to urge his arguments with great force. He also speaks in a deep and loud-tone voice. Nor are these disputes carried on in a long course of various argumentation; but the question is put, and the answer given, in a moment. I am sensible, and have sufficiently experienced, how it sometimes happens that persons are found dead in their beds in a morning. $\mathrm{He}$ is not only able to kill or strangle the body, but knows how to urge and close in the soul with his disputations, that it is obliged to quit the body in an instant-a state into which he had nearly reduced me more than once. For no mortal can endure and withstand them, without the peculiar assistance and power of God."

With this conpare what Whitfield says in his journal, about whom a report was once raised that he was mad, and who says of himself that " he night very well be taken to be really mad, and that his relations counted his life madness." "One morning, rising from my bed, I felt an unsual impres. sion and weight upon my chest. In a short time, the loud gradually increased and almost weighed me down, and fully convinced me that Satan had as real possession of my body as once of Job's. . . . I fancied myself like a man locked up in iron armour; I felt great heavings in my body; prayed under the weight till the sweat came. How many nights did I lie groaning under the weight, bidding Satan depart from me in the name of Jesus."

If these earnest men were mad, then how far gone in madness must the psalmist have been when he cried out, "Many oxen are come aboul me ; fat bulls of Basan close me in on every side." Hallucinations these, surely, of an extreme kind. Which of the great prophetic writers of the Bible will escape the suspicion of insanity, if a vehement sincerity of nature, an exalted imagination, and burning words of passionate earnestness taking a figurative expression, are to be deemed indications of mental unsoundness ?

It cannot be questioned that Lulher was of a vehement nature, intensely earnest, ardently imaginative, obstinate even to rashness, as a man fighting the battle which he fought had need to be. By an incessant application to 
study, and by a sedentary life, he had greatly injured his health, so that he actually heard the noise "which the devil made to torment him;" and on one occasion he was certainly cured by exercise and medicines sent him by Spalatinus. Notwithstanding these things we are of opinion that any one who eugages to prove him insane, wrongly measuring the style and habit of thought of one age by those of another age, will have to make use of argaments which, if they were worthy anything, would prove most of the great and earnest reformers whom the world has seen to have been insane also. Was not Socrates mad, in whose ears a demon constantly whispered what he should do ? Numa could not have been of sound mind, inasmuch as a certain nymph, whom be called Egeria, appeared to him in a cavern. Would not such an acknowledgment be a decisive "fact" in any medical certificate ? Was Mahomet sane, to whom an angel called Gabriel paid regular visits ? We say nothing of George Fox; or of Ignatius Iuoyola, that "errant, shatter-brained, visionary fanatic." Of Oliver Cromwell's grievous madness some minds will entertain no doubt. Did not a spectre appear to him in the open day; and a strange woman open the curtains of his bed at night, to predict to him that he should be King of England? Moreover, he was subject to uncoritrollable fits of laughter on serious occasions. "One that was at the battle of Dunbar," says Aubrey, "told me that Oliver was carried on by a divine impulse. He did laugh so excessively, as if he had been drunk. The same fit of laughter seized him just before the battle of Naseby." But we must make an end of instances, which might be multiplied indefinitely.

It may be well to conclude by suggesting for consideration this question, not whether some touch of madness may not be detected in every great genius, but whether, under the system of indiscriminate sequestration of the insane at present in fashion, some great genius, having a slight touch of madness, is not unnecessarily ending his days in an asylum. Can any one, after reading the autobiography of Benvenuto Cellini, doubt that, if that great artist had lived now, instead of three hundred years ago, he would have lived and died in a lunatic asylum, and that thus the world would have been defrauded of the best fruits of his genius ?-British Medical Jowrnal, May 18.

\section{Recent Contributions to Mental Philosophy.*}

(Soe 'Journal of Mental Science,' October, 1866.)

Tre Nature of Things is a great subject, and one that solicits our atten. tion in many forms.

It has happened to many of our readers to look into a shop, attracted by some article in the window, with the desire of buying one or two for trial, and to be met with the answer, Sir! we do not sell less than a dozen. It may be supposed that we have taken up this plan with respect to works in

- 1. 'Essays for the Times on Ecclesiastical and Social Subjects.' By J. H. Rigg, D.D. (Stock.)-2. 'Faith and Philosophy. Essays on some Tendencies of the Day.' By the Rev. J. Gregory Smith. (Longmans and Co.)-3: 'The Com. mandments considered as Instruments of National Reformation.' By F. D. Maurice. (Macmillan and Co.)-4. 'Benedicite; or, the Song of the Three Children.' By G. Chaplin Child, M.D. 2 vols. (Murray.)-5. 'The Rise and the Fall; or, the Origin of Modern Evil.' (Low and Co.)-6. 'Lectures on Greek Philosophy ; and other Philosophical Remains of J. F. Ferrier.' 2 vols. (Blackwood and Sons.) -7. 'The Philosophy of the Conditioned: comprising some Bemarks on Sir W. Hamilton's Philosophy, and on Mr. J. S. Mill's Examination 